\title{
Antioxidant, ACE-Inhibitory and antibacterial activities of Kluyveromyces marxianus protein hydrolysates and their peptide fractions
}

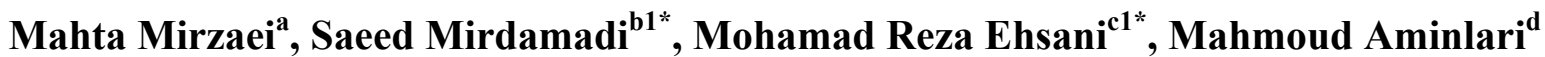 \\ a Department of Food Science and Technology, Shahr-e-Qods Branch, Islamic Azad University, \\ Tehran, Iran; ${ }^{b}$ Department of Biotechnology, Iranian Research Organization for Science \& \\ Technology (IROST), Tehran, Iran; ${ }^{c}$ Department of Food Science and Technology, Science and \\ Research Branch, Islamic Azad University, Tehran, Iran; ${ }^{\mathrm{d}}$ Department of Biochemistry, School \\ of Veterinary Medicine, Shiraz University, Shiraz, Iran \\ *These authors contributed to this work equally. \\ Corresponding Author: Saeed Mirdamadi and Mohamad reza Ehsani \\ Submission Date: February 16th, 2016, Accepted Date: July 27th, 2016, Publication Date: July \\ 30th, 2016

\begin{abstract}
:
Background: There has been evidence that proteins are potentially excellent source of antioxidants, antihypertensive and antimicrobial peptides, and that enzymatic hydrolysis is an effective method to release these peptides from protein molecules. The functional properties of protein hydrolysates depends on the protein substrate, the specificity of the enzymes, the conditions used during proteolysis, degree of hydrolysis, and the nature of peptides released including molecular weight, amino acid composition, and hydrophobicity.
\end{abstract}

Context and purpose of this study: The possibility of using strain of Kluyveromyces marxianus as a source of yeast extract with antioxidant, antibacterial, and ACE-inhibitory activity was the subject of this research.

Results: Autolysis and enzymatic hydrolysis were completed respectively, after $96 \mathrm{~h}$ and $5 \mathrm{~h}$. Overall, trypsin $(18.52 \% \mathrm{DH})$ and chymotrypsin $(21.59 \% \mathrm{DH})$ treatments were successful in releasing antioxidant and ACE inhibitory peptides. Autolysate sample $(39.51 \% \mathrm{DH})$ demonstrated poor antioxidant and ACE inhibitory activity compared to trypsin and chymotrypsin hydrolysates. The chymotrypsin 3-5 kDa (301.6 $\pm 22.81 \mu \mathrm{M} \mathrm{TE} / \mathrm{mg}$ protein) and trypsin $<3 \mathrm{kDa}(280.16 \pm 39.16 \mu \mathrm{M} \mathrm{TE} / \mathrm{mg}$ protein) permeate peptide fractions showed the highest DPPH radical scavenging activity. The trypsin $<3 \mathrm{kDa}$ permeate peptide fraction showed the highest ABTS radical scavenging $(1691.1 \pm 48.68 \mu \mathrm{M} \mathrm{TE} / \mathrm{mg}$ protein) and ACE inhibitory $\left(\mathrm{IC}_{50}=0.03 \pm 0.001 \mathrm{mg} / \mathrm{mL}\right)$ activities. The fraction $(\mathrm{MW}=5-10 \mathrm{kD})$ obtained after autolysis treatment showed antibacterial activity against St. aureus and Lis. monocytogenes in well diffusion screening. The minimum inhibitory concentration (MIC) value was $13.3 \mathrm{mg} / \mathrm{mLagainst}$ St. aureus and Lis. monocytogenes calculated by turbidimetric assay and it showed bactericidal activity against St. aureus at $21.3 \mathrm{mg} / \mathrm{mL}$ protein concentration. 
Conclusions: Altogether, the results of this study reveal that $K$. marxianus proteins contain specific peptides in their sequences which can be released by enzymatic hydrolysis and autolysis.

Key words: Kluyveromyces marxianus, Antioxidant activity, ACE-inhibitory, Antimicrobial activity, Protein hydrolysate, Bioactive peptide.

\section{INTRODUCTION}

The nutritional properties of food proteins have been investigated for many years; food proteins depend on their amino acid content. Recently, there has been some evidence that proteins are potentially excellent sources of antioxidants, antihypertensive, and antibacterial peptides. Furthermore, the possibility of releasing the biologically active peptides from food proteins has gained a lot of interest due to their effects on numerous physiological functions of the organisms. They exhibit antimicrobial, antioxidative, hypocholesterolemic, immunomodulatory, and opioid activities, as well as blood pressure lowering effects (ACE-inhibitory) and enhancement of mineral absorption [1,2]. Enzymatic hydrolysis is an effective method for releasing these peptides from protein molecules [3]. Protein hydrolysates have been used in food supplements, infant foods, sport nutrition products, and functional foods, as well as for the nutritional management of consumers with digestive problems [2]. Oxidation is an important reason of food spoilage. Furthermore, it was confirmed that generation of radicals during oxidation is related to the progress of many diseases including cardiovascular disease, diabetes, inflammatory disease and aging [4]. Consequently, protection against free radicals is a key factor in preventing diseases and deterioration of foods. The use of synthetic antioxidants in food products is under strict regulation. Therefore, the search for natural and safe antioxidants from various natural sources has been gaining much interest [5].

Hypertension is one of the risk factors for cardiovascular diseases. It is well known that the renin-angiotensin system plays an important role in the regulation of blood pressure. The angiotensin-converting enzyme (ACE) catalyzes the hydrolysis of the inactive decapeptide angiotensin I to the potent vasoconstrictor angiotensin II [6].

As many pathogenic bacteria have acquired resistance toward antibiotics, it is therefore important to seek for possible new natural antibiotics e.g. antibiotic peptides or cationic peptides [7]. There has been some evidence that proteins can yield antioxidants, antihypertensive and antimicrobial peptides, and enzymatic hydrolysis is an effective method for releasing these peptides from protein molecules [3].

The antioxidant and antihypertensive and antibacterial activities of protein hydrolysates depend on the protein substrate, the specificity of the enzymes, the conditions used during proteolysis, degree of hydrolysis, and the nature of the peptides released, including molecular weight, amino acid composition, and hydrophobicity [8]. Numerous animal and plant food proteins, mainly milk proteins, casein and whey, egg and meat muscle proteins, have been used for producing bioactive peptides. Based on current literature, food proteins are selected as sources of bioactive peptides based on a value-added use of abundant underutilized proteins or protein-rich food industry by-products, and containing specific peptide sequences or amino acid residues of particular pharmacological interest [9]. 
In recent years, Kluyveromyces marxianus has been used for the large-scale production of single cell protein (SCP) [10]. It has been discovered that yeast protein has a high proportion of hydrophobic and basic residues and may have the potential to prepare protein hydrolysates with antioxidant, antimicrobial and antihypertensive activities [11].

To the best of our knowledge, there is no report on the biological activity of yeast extract obtained from $K$. marxianus. The possibility of using strain of $K$. marxianus as a source of yeast extract with antioxidant, ACE-inhibitory and antimicrobial activity, in addition to considering the activity of different peptide size fractions, were the subject of this research.

\section{MATERIALS AND METHODS}

\section{Materials}

Kluyveromyces marxianus (PTCC 5195) was obtained from Persian Type Culture Collection (PTCC) of the Iranian Research Organization for Science and Technology (IROST). Chymotrypsin (EC 3.4.21.1, containing 55 unit/mg solid), trypsin (EC3.4.21.4; containing 1300 BAEE unit/mg solid), ortho-phthaldialdehyde (OPA), 2,2-diphenyl-1-picryl-hydrazyl (DPPH) and 2,2'-azinobis (3-ethyl-benzothiazoline-6-sulfonate) $\left(\mathrm{ABTS}^{+}\right.$), furanacrylolyl tripeptide (FAPGG) and 6-hydroxy-2, 5, 7, 8-tetramethylchroman-2- carboxylic acid (trolox) were obtained from Sigma-Aldrich Chemie GmbH (Munich, Germany). Other chemicals were of analytical grade.

\section{Culture conditions}

$K$. marxianus was aerobically grown in Yeast Mold (YM) culture at $28{ }^{\circ} \mathrm{C}$ and $150 \mathrm{rpm}$ in an shaking incubator (IRC-1-U ). Cells were harvested in middle of logarithmic phase by centrifugation at $3000 \times \mathrm{g}$ for $10 \mathrm{~min}$. The yeast pellet was washed with distilled water three times and stored at $-20{ }^{\circ} \mathrm{C}$.

\section{Preparation of yeast autolysate samples}

The yeast cells were collected and washed with distilled water. Suspensions of $2.5 \%$ dry yeast cells in $50 \mathrm{~mL}$ distilled water was incubated at $52^{\circ} \mathrm{C}$, pH 5 [12] with agitation at $120 \mathrm{rpm}$ for up to $96 \mathrm{~h}$. Samples were withdrawn at every $24 \mathrm{~h}$, heated at $85^{\circ} \mathrm{C}$ for $15 \mathrm{~min}$ to terminate enzyme activity [13], and cooled down to $4{ }^{\circ} \mathrm{C}$. Cellular debris was removed by centrifugation at $11500 \times \mathrm{g}$ for $10 \mathrm{~min}$ at $4{ }^{\circ} \mathrm{C}$.

\section{Preparation of samples by enzymatic treatment}

To obtain protein extract, suspensions of $2.5 \%$ dry yeast cells in $50 \mathrm{~mL}$ distilled water were disrupted by a sonicator (Part NO. S-4000) at a fixed power of $600 \mathrm{~W}$, frequency of $20 \mathrm{kHz}$ and amplitude of $50 \%$. Total cycle time for ultrasonic treatment was $10 \mathrm{~min}$. The pulse duration and pulse intervals were each one minute. The jar was immersed in an ice-water bath to avoid increasing temperature during sonication. The cellular debris and particles were removed by centrifugation at $11500 \times \mathrm{g}$ for $10 \mathrm{~min}$. The intrinsic yeast cell enzymes in the supernatant were inactivated by heating at $85{ }^{\circ} \mathrm{C}$ for $15 \mathrm{~min}$. The protein concentration of supernatant was measured and adjusted to $4 \mathrm{mg} / \mathrm{mL}$ using phosphate buffer (50 mM, pH 7.8). 
The solution of extracted protein was subjected to trypsin and chymotrypsin hydrolysis. The ratio of protein substrate to each enzyme was $10: 1$. After the 5 -h incubation at $37{ }^{\circ} \mathrm{C}$, the enzymatic hydrolysis was stopped by heating in water $\left(85^{\circ} \mathrm{C}, 15 \mathrm{~min}\right)$. The control sample was considered as a sample which contains just intrinsic yeast cell enzymes [14].

\section{Protein assay}

The total protein content of yeast cells was measured by the Kjeldahl method via multiplication of the total nitrogen by 6.25 [15]. The soluble protein content of supernatant during autolysis and physical-enzymatic treatment was determined by Lowry's method, modified by Hartree [16] using bovine serum albumin (BSA) as the protein standard [16, 17].

\section{Evaluation the degree of hydrolysis}

This assay is used for reaction of free $\alpha$-amino nitrogen with o-phthaldialdehyde (OPA) [18-20]. A fresh OPA solution was prepared daily as follows: $25 \mathrm{~mL}$ of $100 \mathrm{mM}$ sodium tetrahydroborate, $2.5 \mathrm{ml}$ of $2 \% \mathrm{SDS}, 40 \mathrm{mg}$ of OPA (dissolved in $1 \mathrm{~mL}$ methanol) and $100 \mu \mathrm{L}$ of $\beta$ - mercaptoethanol were mixed and adjusted to a final volume of $50 \mathrm{~mL}$ with distilled water. To assay proteolysis with yeast protein as substrate, 10-50 $\mu \mathrm{L}$ aliquots containing 5-100 $\mu$ g protein was added directly to $1 \mathrm{~mL}$ of OPA reagent. The solution was mixed briefly and incubated for 2 $\min$ at room temperature. Subsequently the absorbance was read at $340 \mathrm{~nm}$ using a spectrophotometer (Jenway, Model 6315). L-leucine $(0-4 \mathrm{mg} / \mathrm{mL}$ ) was used to construct a standard curve and free amino groups were calculated using standard curve. The DH value was calculated using following formula:

$$
\mathrm{DH}=\frac{L 1-L 0}{L \max -L 0}
$$

L1: The number of free amino groups released after hydrolysis.

L0: The numbers of free amino groups in the original yeast extract.

$\mathrm{L}$ max: The total numbers of free amino groups in the original yeast extract obtained after acid hydrolysis $\left(6 \mathrm{~N} \mathrm{HCl}\right.$ at $120^{\circ} \mathrm{C}$ for $\left.24 \mathrm{~h}\right)$.

\section{Measurement of antioxidant activity}

The antioxidant activity was measured based on DPPH and $\mathrm{ABTS}^{+}$radical-scavenging activity according to the methods described by Son and Lewis [21] and Re et al. [22], respectively, as explained in our last paper [14]. Radical-scavenging activity (\%) calculated as follows:

$$
\text { Radical-scavenging activity }(\%)=\frac{A \text { control-A sample }}{\text { Acontrol }} * 100
$$

The trolox standard curves showed a linear concentration response in the range of $0-30 \mu \mathrm{M}$ and 1.5-25 $\mu \mathrm{M}$ of trolox for respectively, DPPH and ABTS assays and were used to determine trolox equivalent antioxidant capacity (TEAC).

\section{Determination of ACE-inhibitory activity}

The rabbit lung powder was prepared following the procedure of Lossow et al. [23] with modifications [14] and ACE-inhibitory activity was measured by the spectrophotometric assay 
[24] . Briefly, furanacrylolyl tripeptide $(75 \mu \mathrm{L}, 5 \mathrm{mM})$ dissolved in $50 \mathrm{mM}$ tris- $\mathrm{HCl}$ buffer $(\mathrm{pH}$ 8.3) containing $400 \mathrm{mM} \mathrm{NaCl}$ and Peptide fractions or water $(25 \mu \mathrm{L})$ were added to each well of Elisa plate and pre-incubated for $20 \mathrm{~min}$ at $37^{\circ} \mathrm{C}$. ACE extract $(10 \mu \mathrm{L})$ was added to the mixture and the absorbance was measured at $340 \mathrm{~nm}$ using an ELISA reader Expert 96 (Power wave xS2, Bioteck, America) for periods of $30 \mathrm{~min}$ at $37^{\circ} \mathrm{C}$. The slope of the decrease in absorbance of samples ( $\triangle \mathrm{A}$ sample) and control $(\triangle \mathrm{A}$ control) as a function of time were calculated and ACEinhibitory activity (\%) was determined as follows [24]:

ACE-inhibitory activity $(\%)=\left(1-\frac{\Delta A \text { sample }}{\Delta A \text { control }}\right) * 100$

The $50 \%$ inhibitory concentration $\left(\mathrm{IC}_{50}\right)$ was determined from a plot of percentage of ACEinhibitory activity against peptide concentration.

\section{Antibacterial activity}

Antibacterial activity of yeast protein hydrolysates and peptide fractions were performed against Bacillus cereus (PTCC 1015), Listeria monocytogenes (PTCC 1306), Staphilococcus aureus (PTCC 1112), Escherichia coli (PTCC 1330), and Micrococcus luteus (PTCC 1110), by the well diffusion method described by Hou, Li [25] with some modification.

An aliquot of bacteria with a titer of $10^{6} \mathrm{CFU} / \mathrm{mL}$ was mixed with $20 \mathrm{~mL}$ Tryptocase soy broth (TSB) medium containing $0.8 \%$ agarose and was poured in a plate. Holes were then created in the medium using a punch. The peptide sample $(50 \mu \mathrm{L})$ was loaded into the wells and the plates were incubated at $37^{\circ} \mathrm{C}$ for $24 \mathrm{~h}$. An aliquot of $5 \mu \mathrm{L}$ nisin $(2000 \mathrm{IU} / \mathrm{mL})$ was used as positive control and water as negative control. For calculating antibacterial activity (\%), each bacterium was first grown separately in $\mathrm{BHI}$ medium at $37^{\circ} \mathrm{C}$ for $24 \mathrm{~h}$. Approximately, $100 \mu \mathrm{L}$ of culture was transferred to new culture and incubated for $3 \mathrm{~h}$ at $37^{\circ} \mathrm{C}$. To a 96-well microplate, 10 $\mu \mathrm{L}$ of bacterial suspension and $15 \mu \mathrm{L}$ of BHI medium were poured. Stock serial dilution of 5.6$26.6 \mathrm{mg} / \mathrm{mL}$ peptides were prepared and $50 \mu \mathrm{L}$ of peptide stocks were added in each well. The microplate was incubated at $37^{\circ} \mathrm{C}$ for $24 \mathrm{~h}$. Later, the absorbance at $600 \mathrm{~nm}$ for each well in zero time and after $24 \mathrm{~h}(\Delta \mathrm{A})$ was read with a microplate reader, with the results then being compared to the control sample. The antimicrobial activity was calculated as follows:

$$
\text { Antibacterial activity }(\%)=100 \times \frac{\Delta A \text { negative control }-\Delta A \text { sample }}{\Delta A \text { negative control }}
$$

The MIC values were determined as the lowest concentration of peptides at which no visible growth was observed. For the determination of Minimum Bactericidal Concentration (MBC), a portion of liquid from each sample that exhibited no visible growth were cultured in the plate and then incubating $37^{\circ} \mathrm{C}$ for $24 \mathrm{hr}$. The lowest concentration that revealed no bacterial growth was taken as $\mathrm{MBC}[7,26,27]$.

\section{Statistical analysis}

In this study the results are the average of triplicate analysis conducted on one application of the treatments. Data are presented as mean value \pm standard deviations. The significance between mean values was determined using independent-samples $T$ test and one-way ANOVA. Statistical analysis was performed in SPSS software, version 20. P value $<0.05$ was considered significant. 


\section{RESULTS AND DISCUSSION}

\section{Antioxidant, ACE inhibitory and antimicrobial activities of yeast peptide fractions}

In this study, $K$. marxianus protein hydrolysates was used as a possible source of ACE inhibitory, antioxidant and antibacterial peptides. The yeast protein hydrolysates were prepared by two different enzymatic (sonication-trypsin and chymotrypsin hydrolysis) and autolysis treatments. Antioxidant activity is expressed as TEAC and ACE inhibitory activity is determined as $\mathrm{IC}_{50}$ value based on inhibiting ACE activity.

\section{Antioxidant activity}

The DPPH and $\mathrm{ABTS}^{+}$radical-scavenging activity of the control sample, trypsin and chymotrypsin hydrolysate, and autolysate samples is shown in figure 1.

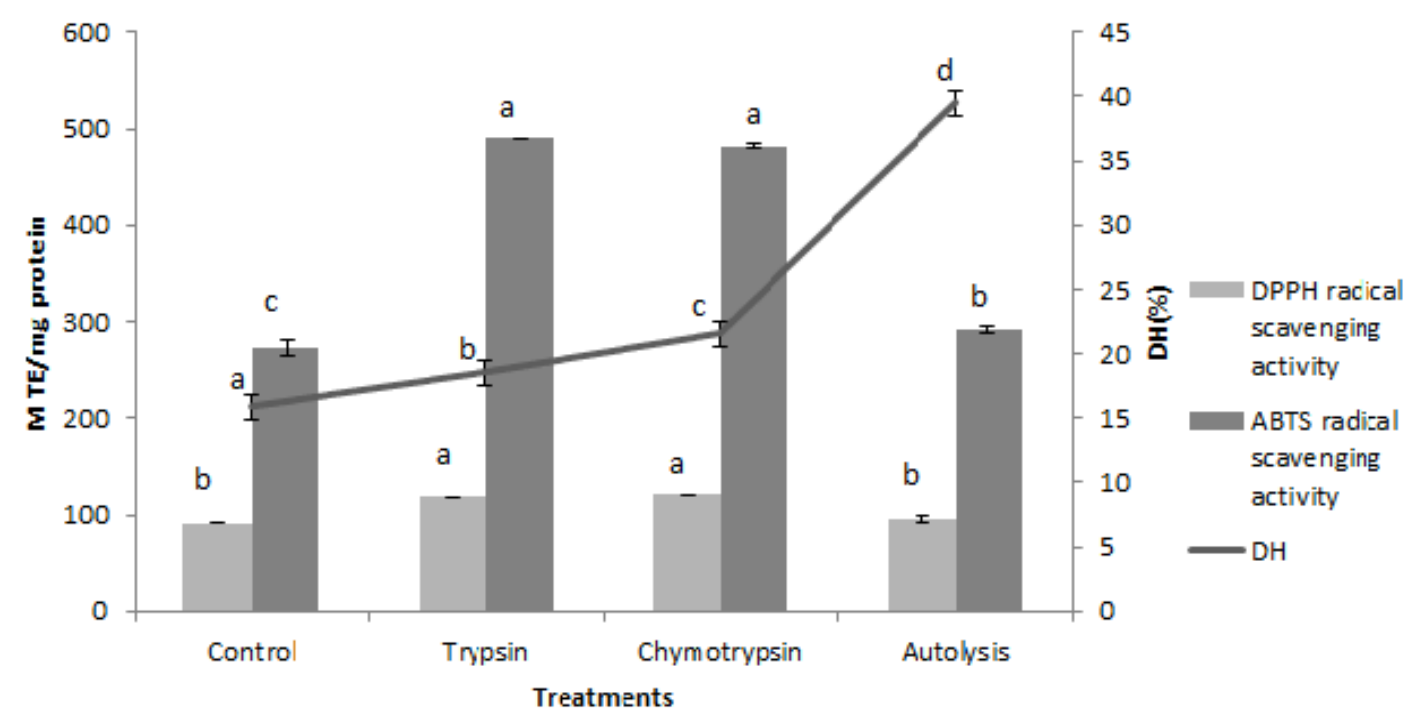

Figure 1. Antioxidant activity of yeast protein hydrolysates. The data of DPPH and ABTS radical-scavenging activities are expressed as trolox equivalent antioxidant capacity $(\mu \mathrm{M} \mathrm{TE} / \mathrm{mg}$ protein). The data of DH were measured using OPA assay and are expressed as percent values. The results are mean values of experiments carried out in triplicate. Values with different letters for each assay are statistically different at $\mathrm{P}<0.05$.

As it can be found, trypsin $(18.52 \% \mathrm{DH})$ and chymotrypsin $(21.59 \% \mathrm{DH})$ hydrolysis causes significant $(\mathrm{P}<0.05)$ increase in $\mathrm{DPPH}$ and $\mathrm{ABTS}^{+}$radical-scavenging activity of protein hydrolysates compare to control sample $(\mathrm{P}<0.05)$. It can be explained by a better exposure of the antioxidant amino acid residues due to peptide bonds cleavage. Tyr, Trp, Met, Lys and His, and aromatic amino acids improve the radical scavenging properties of amino acid residues and the $\mathrm{SH}$ group in cysteine has a crucial antioxidant action due to its direct interaction with radicals [28]. Additionally, it has been reported that during hydrolysis, the protein chains unfold and results in the development of hydrophobicity and so antioxidant activity of protein hydrolysates, since the balance between hydrophilic and hydrophobic forces of peptides has a crucial influence on the solubility of protein hydrolysate and its antioxidant activity [28-32] . 
The differences between trypsin and chymotrypsin were not significant $(\mathrm{P}>0.05)$ in DPPH and ABTS assay (figure 1). As it was previously reported by Pihlanto [31], the antioxidant activity of protein hydrolysates is influenced by characteristic amino acid sequences of derived peptides, depending on the protease specificity. Protease specificity affect amount, size, composition and amino acid sequence of producing peptides which in turn influences the antioxidant activity of the hydrolysates [33-35]. These observations suggest that trypsin and chymotrypsin digestion resulted in hydrolysis of inactive peptides within the protein and release of shorter peptides with radical-scavenging activity. Probably, hydrophobic amino acid side chain groups are exposed by tryptic and chymotryptic digestion, which might increase their ability to scavenge free radicals as it was previously reported by You, Zhao [36], and Memarpoor-Yazdi, Mahaki [37].

According to the results of this research (figure 1), the autolysate sample $(39.51 \% \mathrm{DH})$ showed the lowest DPPH $\left(94.96 \pm 3 \mu \mathrm{m} \mathrm{TE} / \mathrm{mg}\right.$ protein) and $\mathrm{ABTS}^{+}(292.23 \pm 3.4 \mu \mathrm{m} \mathrm{TE} / \mathrm{mg}$ protein) radical-scavenging activity. Our results indicated that antioxidant activity does not necessarily increase with DH. Jun, Park [38] also reported that the lowest DH of pepsin hydrolyzed yellow fin sole frame exhibited the highest antioxidant activity than those hydrolyzed by alcalase and trypsin. Wiriyaphan et al. Wiriyaphan, Chitsomboon [39] also reported that threadfin bream surimi by products hydrolysate prepared by pepsin $(5 \% \mathrm{DH})$ and Virgibacillus SP. SK33 proteinase $(13 \% \mathrm{DH})$ showed higher $\mathrm{ABTS}^{+}$radical-scavenging activity than the hydrolysate prepared by alcalase $(27 \% \mathrm{DH})$ and trypsin $(11 \% \mathrm{DH})$. Wang, Li [32] also reported the same results. Deeper hydrolysis, may change the conformation of producing peptides, with enhancing levels of free amino acid carboxyl groups resulting in enhanced solubility [28, 40]. Additionally, it can contribute to the production of too much amino acids during extensive proteolysis. Peptides are potentially better antioxidants than amino acids, due to unique chemical and physical properties related to their amino acids sequences [38, 39]. Therefore, too many free amino acids produced as a result of extensive proteolysis may reduce the antioxidant activity of protein hydrolysate.

As can be seen in figure 1, TEAC levels determined by the ABTS radical cation decolorization method were significantly $(\mathrm{P}<0.05)$ higher than those measured by DPPH assay. It can be explained by more reactivity of $\mathrm{ABTS}^{+}$radical toward most antioxidants, as it was previously reported by Martysiak-Zurowska and Wenta [41] for human milk. They also reported the lower sensitivity of DPPH assay when compared to ABTS radical cation decolorization assay and our results confirm it.

\section{ACE inhibitory activity}

In the present study, in vitro ACE-inhibitory activity of the final products of autolysis and physical-enzymatic treatments was also investigated. The ACE-inhibitory activity is expressed as $\mathrm{IC}_{50}$ value based on inhibiting ACE-activity.

Results (figure 2) revealed that the ACE-inhibitory activity of the yeast protein hydrolysate was influenced by the type of enzymatic treatment. Trypsin $\left(15.91 \% \mathrm{DH}, \mathrm{IC}_{50}=0.49 \pm 0.009\right.$ $\mathrm{mg} / \mathrm{mL}$ ) and chymotrypsin ( $21.59 \% \mathrm{DH}, \mathrm{IC}_{50}=0.51 \pm 0.01 \mathrm{mg} / \mathrm{ml}$ ) were the most effective. These results indicated that enzymes specificity plays an important role in the preparation of bioactive peptides and tryptic and chymotryptic digestion resulted in more ACE-inhibitory 
activity of protein hydrolysate. As it can be seen from the results, the higher DH value obtained during autolysis caused no significant $(\mathrm{P}>0.05)$ increase in ACE-inhibitory activity of protein hydrolysate. It may be due to the type of active enzymes during autolysis and extent of proteolysis. As it was previously reported by Chen et al. [42] extensive proteolysis may lead to disruption of peptides that were previously generated and so decreasing ACE-inhibitory activity.

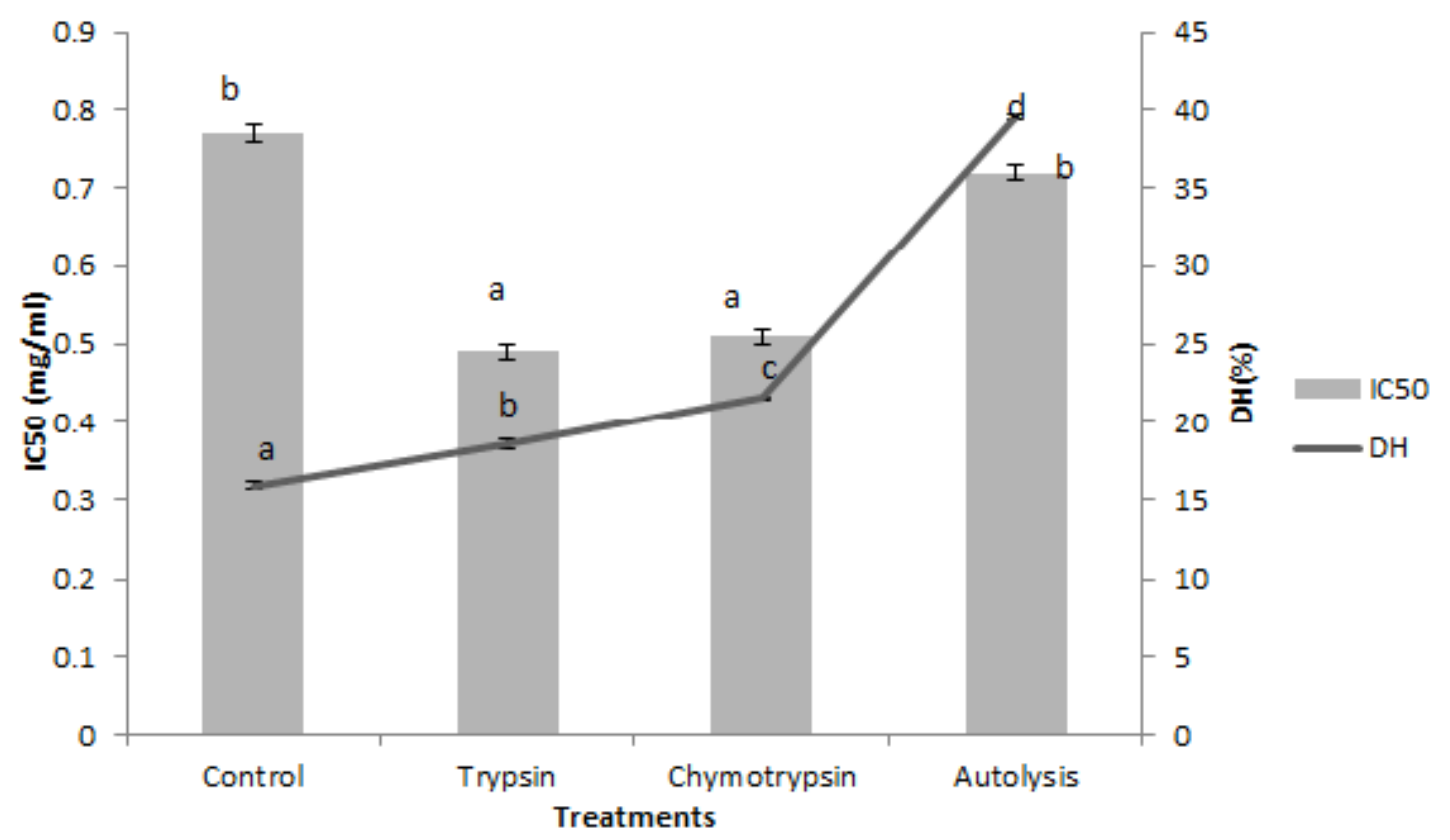

Figure 2. ACE-inhibitory activity of yeast protein hydrolysates. $\mathrm{IC}_{50}$ is the concentration $(\mathrm{mg} / \mathrm{mL})$ of an ACE inhibitor needed to inhibit $50 \%$ of ACE activity. The results are mean values of experiments carried out in triplicate. Values with different letters in each column are statistically different at $\mathrm{P}<0.05$.

Although the structure-activity relationship of ACE-inhibitory peptides from food proteins is not fully studied, it is known that the binding of inhibitory peptides to ACE is strongly influenced by the C-terminal sequence and hydrophobic amino acids e.g., Proline, are more active if present at each of the three $\mathrm{C}$-terminal sequence. Additionally, the presence of the positive charge of Lys and Arg as the C-terminal residue may contribute to the inhibitory activity [43]. Based on López-Fandiño, Otte [43], enzymes with specificity towards the carboxylic side of aromatic or other hydrophobic amino acid residues or the basic amino acids may be useful for producing ACE-inhibitory peptides. These observations suggest that trypsin and chymotrypsin hydrolysis were the most effective for releasing ACE inhibitory peptides from parent protein. Salami, Moosavi-Movahedi [44] also reported the increasing in ACE inhibitory activities of camel whole casein and camel $\beta-\mathrm{CN}$ after trypsin and chymotrypsin hydrolysis.

\section{Antibacterial activity}

Preliminary assay for antimicrobial activity was carried out using crude hydrolysate and autolysate with protein concentration of $4 \mathrm{mg} / \mathrm{mL}$. They exhibited no antibacterial activity in well diffusion assay against the tested strains. It can be explained by low peptide concentration 
as it was previously reported by Sibel Akalın [45]. Thus, the antibacterial activity was examined after partial purification by ultrafiltration technique.

\section{Antioxidant, ACE inhibitory and antimicrobial activities of yeast peptide fractions}

The ultrafiltration was used to perform peptide separation according to their molecular weight. Trypsin and chymotrypsin hydrolysates and autolysate were fractionated using membranes with molecular weight cut-off of 3,5, and $10 \mathrm{kDa}$. The DPPH and ABTS radical scavenging activities of yeast protein hydrolysates and autolysate and their UF-fractions are presented in figure 3 and 4.

Our results (figure 3, 4, 5) confirm that peptide size has substantial influence on the antioxidant and ACE inhibitory activities of yeast protein hydrolysates and their peptide fractions. Onuh, Girgih [46] also reported that the antioxidant activity of hydrolysates were closely associated with the MW distributions and it is reported that a common feature of ACEinhibitory peptides is their relatively restricted size [43]. The chymotrypsin 3-5 kDa (301.6 $\pm 22.81 \mu \mathrm{M} \mathrm{TE} / \mathrm{mg}$ protein) and trypsin $<3 \mathrm{kDa}(280.16 \pm 39.16)$ permeate peptide fractions showed the highest DPPH radical scavenging activity (figure 3 ). The trypsin $<3 \mathrm{kDa}$ permeate peptide fraction showed the highest ABTS radical scavenging (1691.1 $\pm 48.68 \mu \mathrm{M} \mathrm{TE} / \mathrm{mg}$ protein) (figure 4) and ACE inhibitory (IC50=0.03 $\pm 0.001 \mathrm{mg} / \mathrm{mL}$ ) (figure 5) activities.
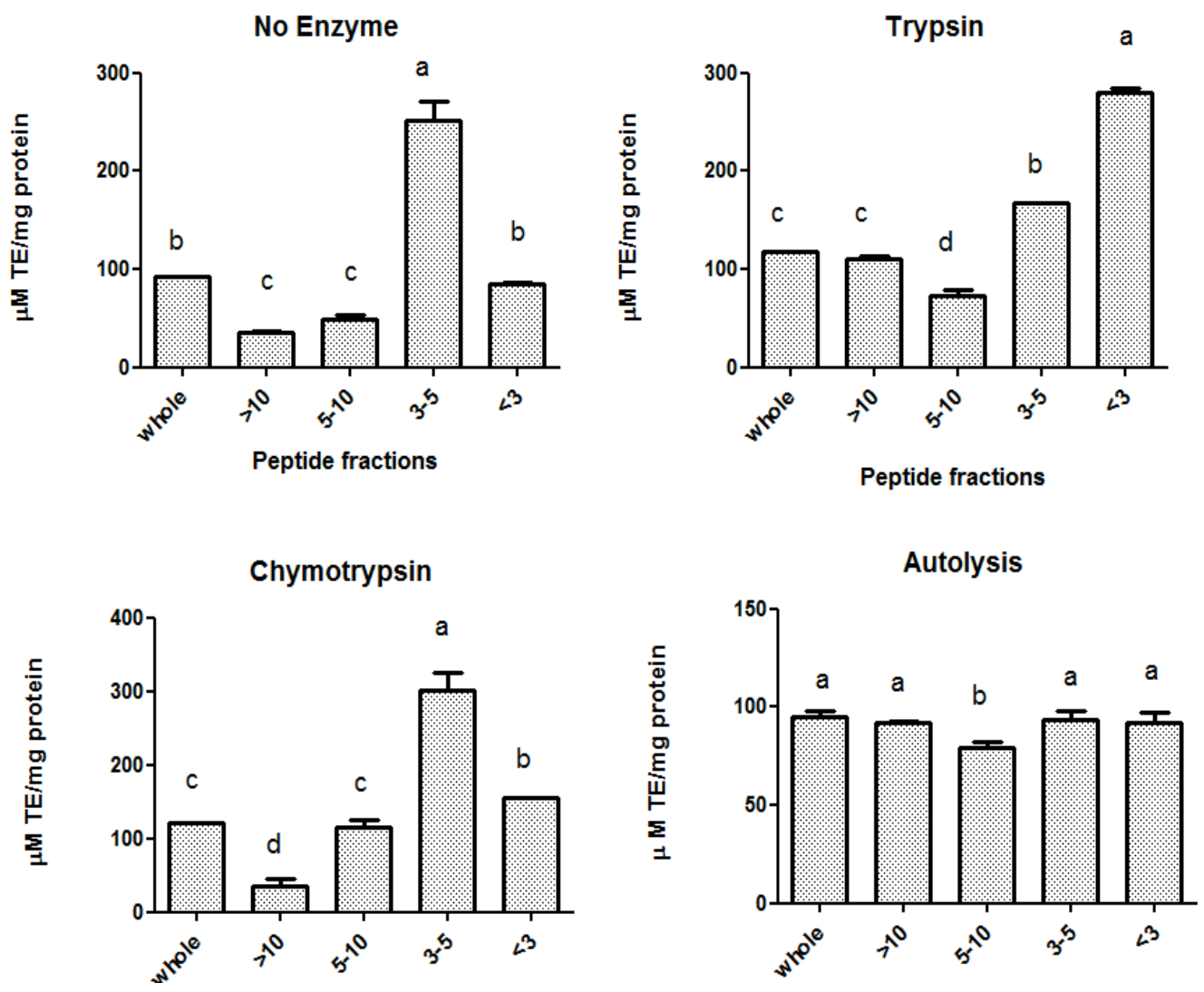

Figure 3. DPPH radical-scavenging activity of whole yeast protein hydrolysates (physical-trypsin hydrolysate, physical-chymotrypsin hydrolysate) and their peptide fractions. The data are expressed as trolox equivalent antioxidant capacity ( $\mu \mathrm{M} \mathrm{TE} / \mathrm{mg}$ protein). The results are mean values of experiments carried out in triplicate. Data marked with asterisk are not statistically different at $\mathrm{P}<0.05$. 

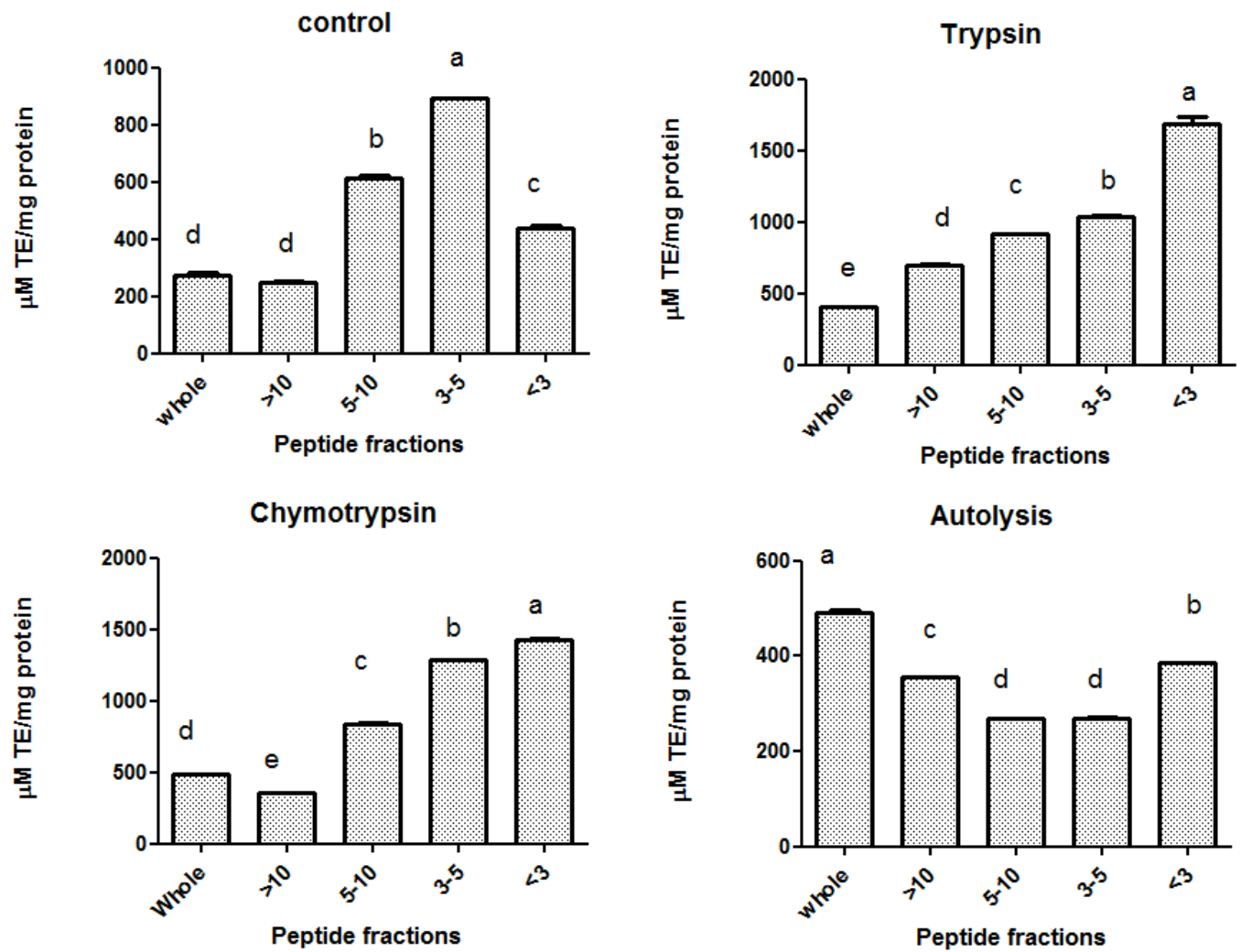

Figure 4. ABTS radical-scavenging activity of whole yeast protein hydrolysates (physicaltrypsin hydrolysate, physical-chymotrypsin hydrolysate) and their peptide fractions. The data are expressed as trolox equivalent antioxidant capacity ( $\mu \mathrm{M} \mathrm{TE} / \mathrm{mg}$ protein). The results are mean values of experiments carried out in triplicate. Data marked with asterisk are not statistically different at $\mathrm{P}<0.05$.

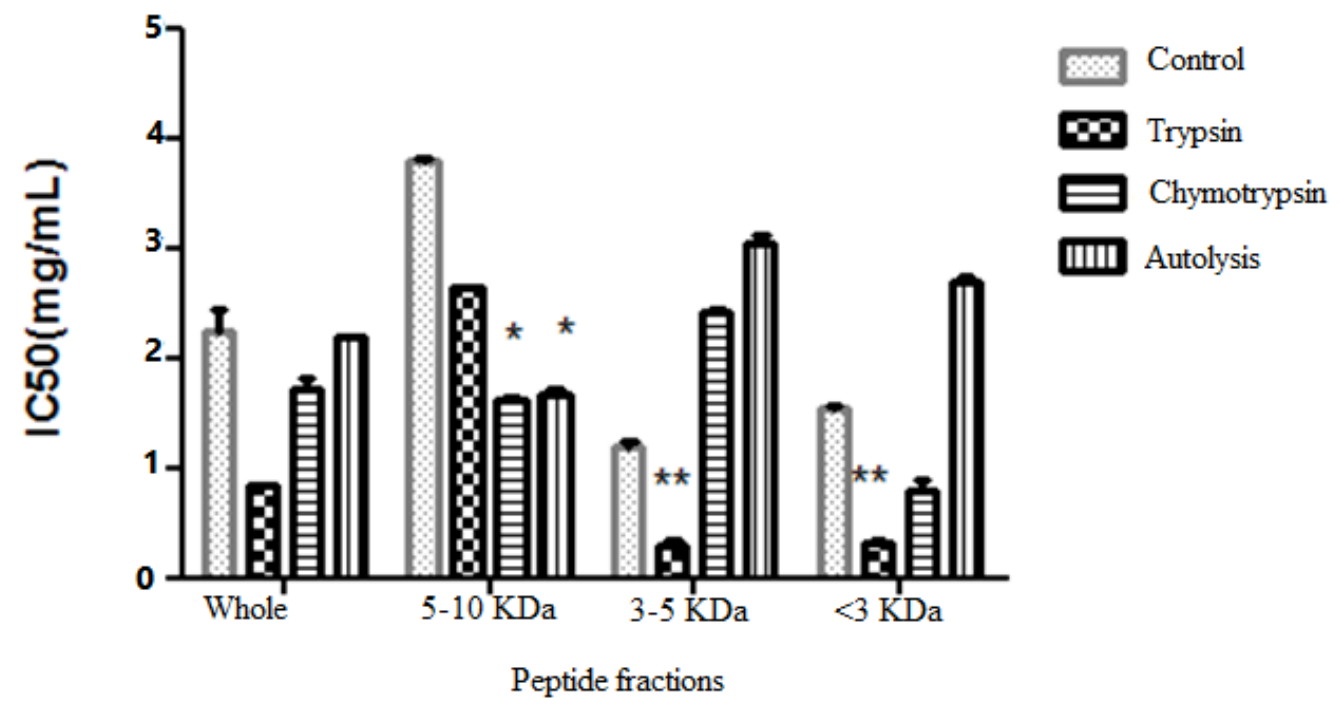

Figure 5. The size dependent ACE-inhibitory activity of yeast protein hydrolysates and autolysate and their peptide fractions. IC50 is the concentration $(\mathrm{mg} / \mathrm{mL})$ of an ACE inhibitor needed to inhibit $50 \%$ of ACE activity. Data marked with asterisk are not significantly different $(\mathrm{P}>0.05)$. 
Most the antioxidant and ACE inhibitory peptides are less than $3 \mathrm{kDa}$ and 3-5 kDa and have a significantly higher activity than their parent hydrolysates. This agrees with many reports where the lower molecular weight (LMW) peptides had greater antioxidant and ACE inhibitory activities than those of the larger peptides [47] due to more effective interaction with radicals intervening in the oxidizing process [8]. As it was previously reported, this is the case for barley hordein protein fractions [48], hemp hydrolysates [49] and canola meal protein hydrolysate [50]. Mullally, Meisel [51] also found the highest ACE inhibitory peptides in the $3 \mathrm{kDa}$ permeates, compared with the 1 and $10 \mathrm{kDa}$ permeates and with the original tryptic digest of whey protein.
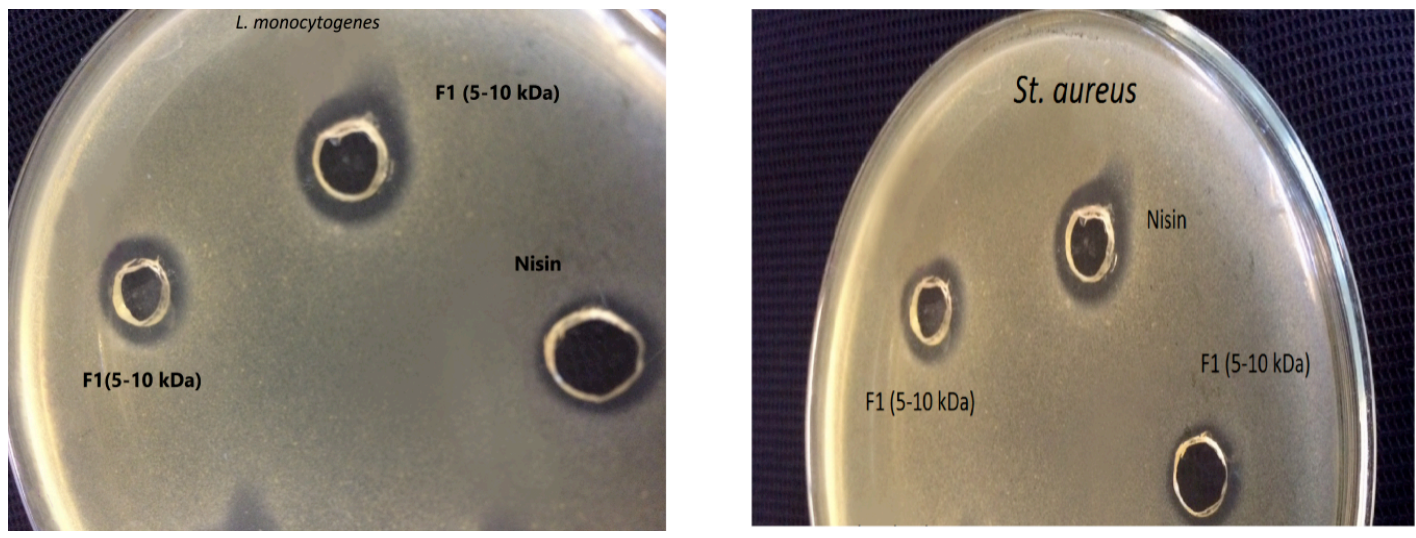

Figure 6. Inhibition zone of peptide fraction $(5-10 \mathrm{kDa})$ in two plate containing $L$. monocytogenes and St. aureus in well diffusion assay.

The fraction (MW=5-10 kD) obtained after autolysis of $K$. marxianus showed antibacterial activity against St. aureus and Lis. monocytogenes in well diffusion screening (Figure 6). Peptide length is an important factor for the interaction of bioactive peptides and phospholipid membranes. Peptides need to be able to span the thickness of the membranes to stabilize the pore and exhibit antibacterial activity. In addition, by decreasing peptide lengths, the tendency of peptides to form ordered secondary structure will be reduced [52] and these can explain the higher efficiency of peptide fraction with $\mathrm{MW}=5-10 \mathrm{kDa}$.

Growth inhibitory (\%) activity of peptide fraction was calculated as it was described in material and method section. The results are presented in table 1.

Table 1. ACE inhibitory and antioxidant activity of yeast protein hydrolysates

\begin{tabular}{|l|l|l|l|l|}
\hline Samples & DH(\%) & IC50 $(\mathbf{m g} / \mathbf{m l})$ & $\begin{array}{l}\text { DPPH radical } \\
\text { scavenging activity } \\
(\boldsymbol{\mu M} \text { TE/mg protein })\end{array}$ & $\begin{array}{l}\text { ABTS radical scavenging } \\
\text { activity }(\boldsymbol{\mu M} \text { TE/mg } \\
\text { protein })\end{array}$ \\
\hline Control & $15.91^{\mathrm{a}}$ & $0.77 \pm 0.01^{\mathrm{b}}$ & $91.85 \pm 0^{\mathrm{b}}$ & $273.04 \pm 8.63^{\mathrm{c}}$ \\
\hline $\begin{array}{l}\text { Physical-trypsin } \\
\text { hydrolysis }\end{array}$ & $18.52^{\mathrm{b}}$ & $0.49 \pm 0.009^{\mathrm{a}}$ & $118.53 \pm 0^{\mathrm{a}}$ & $489.53 \pm 0^{\mathrm{a}}$ \\
\hline $\begin{array}{l}\text { Physical- } \\
\text { chymotrypsin } \\
\text { hydrolysis }\end{array}$ & $21.59^{\mathrm{c}}$ & $0.51 \pm 0.01^{\mathrm{a}}$ & $121.11 \pm 0^{\mathrm{a}}$ & $482.03 \pm 2.34^{\mathrm{a}}$ \\
\hline Autolysis & $39.51^{\mathrm{d}}$ & $0.72 \pm 0.01^{\mathrm{b}}$ & $94.96 \pm 3^{\mathrm{b}}$ & $292.23 \pm 3.4^{\mathrm{b}}$ \\
\hline
\end{tabular}


$\mathrm{IC}_{50}$ is the concentration $(\mathrm{mg} / \mathrm{ml})$ of an ACE inhibitor needed to inhibit $50 \%$ of ACE activity. The data of DPPH and ABTS radical-scavenging activities are expressed as trolox equivalent antioxidant capacity ( $\mu \mathrm{M} \mathrm{TE} / \mathrm{mg}$ protein). The results are mean values of experiments carried out in triplicate. Values with different letters in each column are statistically different at $\mathrm{P}<0.05$.

This study shows that autolysis of $K$. marxianus can release peptides (MW=5-10 kDa) with antibacterial activities with MIC value of $13.3 \mathrm{mg} / \mathrm{mL}$ against St. aureus and Lis. Monocytogenes. While other peptide fractions showed no activity against tested strains. The antibiotic activity of peptide fraction at $21.3 \mathrm{mg} / \mathrm{mL}$ protein concentration was proven to be lethal for St. aureus as they were not capable of resuming growth on agar plate after $24 \mathrm{~h}$ incubation at $37^{\circ} \mathrm{C}$.

\section{CONCLUSION}

Altogether, the results of this study confirmed that the yeast protein hydrolysates of $K$. marxianus with antioxidant, ACE-inhibitory and antimicrobial activity can be provided through enzymatic hydrolysis and autolysis treatments of yeast cell and peptides size has an important role in their biological activities. They may be beneficial as food additives a functional ingredient, pharmaceutical agents and diet nutrients.

Competing Interests: The authors have no financial interests or conflicts of interest.

Author's Contributions: All authors contributed sufficiently to this work.

\section{Acknowledgements}

This work has been supported by Iranian Research Organization for Science and Technology (IROST) and Islamic Azad University, Shahr-e-Qods Branch.

\section{REFERENCES:}

1. Silvestre, M.P.C., Review of methods for the analysis of protein hydrolysates. Food Chemistry, 1997. 60(2): p. 263-271.

2. Rutherfurd, S.M., Methodology for determining degree of hydrolysis of proteins in Hydrolysates: a review. J AOAC Int, 2010. 93(5): p. 1515-22.

3. Xia, Y., et al., Fractionation and characterization of antioxidant peptides derived from barley glutelin by enzymatic hydrolysis. Food Chemistry, 2012. 134(3): p. 1509-1518.

4. Rao, S., et al., ACE inhibitory peptides and antioxidant peptides derived from in vitro digestion hydrolysate of hen egg white lysozyme. Food Chem, 2012. 135(3): p. 1245-52.

5. Mohamed, T.K., A. Issoufou, and H. Zhou, Antioxidant activity of fractionated foxtail millet protein hydrolysate. International Food Research Journal, 2012. 19(1): p. 207-213.

6. Coates, D., The angiotensin converting enzyme (ACE). Int J Biochem Cell Biol, 2003. 35(6): p. 769-73. 
7. Salampessy, J., et al., Release of antimicrobial peptides through bromelain hydrolysis of leatherjacket (Meuchenia sp.) insoluble proteins. Food Chemistry, 2010. 120(2): p. 556560.

8. He, R., et al., Antioxidant activities of enzymatic rapeseed protein hydrolysates and the membrane ultrafiltration fractions. Journal of Functional Foods, 2013. 5(1): p. 219-227.

9. Udenigwe, C.C. and R.E. Aluko, Food Protein-Derived Bioactive Peptides: Production, Processing, and Potential Health Benefits. Journal of Food Science, 2012. 77(1): p. R11R24.

10. Pas, M., et al., Iron enriched yeast biomass--a promising mineral feed supplement. Bioresour Technol, 2007. 98(8): p. 1622-8.

11. de la Hoz, L., et al., Iron-binding properties of sugar cane yeast peptides. Food Chemistry, 2014. 142(0): p. 166-169.

12. Běehalová, B. and K. Beran, Autolysis of disintegrated cells of the yeast saccharomyces cerevisiae. Acta Biotechnologica, 1986. 6(2): p. 147-152.

13. Tanguler, H. and H. Erten, Utilisation of spent brewer's yeast for yeast extract production by autolysis: The effect of temperature. Food and Bioproducts Processing, 2008. 86(4): p. 317-321.

14. Mirzaei, M., et al., Purification and identification of antioxidant and ACE-inhibitory peptide from Saccharomyces cerevisiae protein hydrolysate. Journal of Functional Foods, 2015. 19, Part A: p. 259-268.

15. AOAC, AOAC international, W. Horwitz, Editor 2000, Gaithersburg: USA.

16. Hartree, E.F., Determination of protein: A modification of the lowry method that gives a linear photometric response. Analytical Biochemistry, 1972. 48(2): p. 422-427.

17. Lowry, O.H., et al., Protein measurement with the Folin phenol reagent. J Biol Chem, 1951. 193(1): p. 265-75.

18. Church, F.C., et al., Spectrophotometric Assay Using o-Phthaldialdehyde for Determination of Proteolysis in Milk and Isolated Milk Proteins1. Journal of Dairy Science, 1983. 66(6): p. 1219-1227.

19. Jamdar, S.N., et al., Influence of degree of hydrolysis on functional properties, antioxidant activity and ACE inhibitory activity of peanut protein hydrolysate. Food Chemistry, 2010. 121(1): p. 178-184.

20. Sun, Q., et al., EFFECTS OF pH, TEMPERATURE AND ENZYME TO SUBSTRATE RATIO ON THE ANTIOXIDANT ACTIVITY OF PORCINE HEMOGLOBIN HYDROLYSATE PREPARED WITH PEPSIN. Journal of Food Biochemistry, 2011. 35(1): p. 44-61.

21. Son, S. and B.A. Lewis, Free radical scavenging and antioxidative activity of caffeic acid amide and ester analogues: structure-activity relationship. Journal of Agricultural and Food Chemistry, 2002. 50(3): p. 468-72.

22. Re, R., et al., Antioxidant activity applying an improved ABTS radical cation decolorization assay. Free Radical Biology and Medicine, 1999. 26(9-10): p. 1231-1237.

23. Lossow, W.J., et al., Effect of total exclusion of the exocrine pancreas in the rat upon in vitro esterification of c14-labeled cholesterol by the intestine and upon lymphatic absorption of c14-labeled cholesterol. J Lipid Res, 1964. 5: p. 198-202. 
24. Vermeirssen, V., J. Van Camp, and W. Verstraete, Optimisation and validation of an angiotensin-converting enzyme inhibition assay for the screening of bioactive peptides. Journal of Biochemical and Biophysical Methods, 2002. 51(1): p. 75-87.

25. Hou, F., et al., Isolation and characterisation of a new antimicrobial peptide from the skin of Xenopus laevis. International Journal of Antimicrobial Agents, 2011. 38(6): p. $510-515$.

26. Asoodeh, A., J. Zardini Hz Fau - Chamani, and J. Chamani, Identification and characterization of two novel antimicrobial peptides, temporin-Ra and temporin-Rb, from skin secretions of the marsh frog (Rana ridibunda). 2012(1099-1387

27. Kang, C.-G., et al., Evaluation of Antimicrobial Activity of the Methanol Extracts from 8 Traditional Medicinal Plants. Toxicological Research, 2011. 27(1): p. 31-36.

28. Sarmadi, B.H. and A. Ismail, Antioxidative peptides from food proteins: a review. Peptides, 2010. 31(10): p. 1949-56.

29. Moure, A., H. Dominguez, and J.C. Parajo, Fractionation and enzymatic hydrolysis of soluble protein present in waste liquors from soy processing. J Agric Food Chem, 2005. 53(19): p. 7600-8.

30. Wang, W. and E.G. De Mejia, A New Frontier in Soy Bioactive Peptides that May Prevent Age-related Chronic Diseases. Comprehensive Reviews in Food Science and Food Safety, 2005. 4(4): p. 63-78.

31. Pihlanto, A., Antioxidative peptides derived from milk proteins. International Dairy Journal, 2006. 16(11): p. 1306-1314.

32. Wang, B., et al., Purification and characterisation of a novel antioxidant peptide derived from blue mussel (Mytilus edulis) protein hydrolysate. Food Chemistry, 2013. 138(2-3): p. 1713-1719.

33. Chen, H.-M., K. Muramoto, and F. Yamauchi, Structural Analysis of Antioxidative Peptides from Soybean .beta.-Conglycinin. J Agric Food Chem, 1995. 43(3): p. 574-578.

34. Jeon, Y.-J., H.-G. Byun, and S.-K. Kim, Improvement of functional properties of cod frame protein hydrolysates using ultrafiltration membranes. Process Biochemistry, 1999. 35(5): p. 471-478.

35. Wu, H.-C., H.-M. Chen, and C.-Y. Shiau, Free amino acids and peptides as related to antioxidant properties in protein hydrolysates of mackerel (Scomber austriasicus). Food Research International, 2003. 36(9-10): p. 949-957.

36. You, L., et al., Changes in the antioxidant activity of loach (Misgurnus anguillicaudatus) protein hydrolysates during a simulated gastrointestinal digestion. Food Chemistry, 2010. 120(3): p. 810-816.

37. Memarpoor-Yazdi, M., H. Mahaki, and H. Zare-Zardini, Antioxidant activity of protein hydrolysates and purified peptides from Zizyphus jujuba fruits. Journal of Functional Foods, 2013. 5(1): p. 62-70.

38. Jun, S.-Y., et al., Purification and characterization of an antioxidative peptide from enzymatic hydrolysate of yellowfin sole (Limanda aspera) frame protein. European Food Research and Technology, 2004. 219(1): p. 20-26. 
39. Wiriyaphan, C., B. Chitsomboon, and J. Yongsawadigul, Antioxidant activity of protein hydrolysates derived from threadfin bream surimi byproducts. Food Chemistry, 2012. 132(1): p. 104-111.

40. Hernandez-Ledesma, B., et al., Preparation of antioxidant enzymatic hydrolysates from alpha-lactalbumin and beta-lactoglobulin. Identification of active peptides by HPLCMS/MS. J Agric Food Chem, 2005. 53(3): p. 588-93.

41. Martysiak-Zurowska, D. and W. Wenta, A comparison of ABTS and DPPH methods for assessing the total antioxidant capacity of human milk. Acta Sci Pol Technol Aliment, 2012. 11(1): p. 83-9.

42. Chen, C., et al., Influence of degree of hydrolysis on functional properties, antioxidant and ACE inhibitory activities of egg white protein hydrolysate. Food Science and Biotechnology, 2012. 21(1): p. 27-34.

43. López-Fandiño, R., J. Otte, and J. van Camp, Physiological, chemical and technological aspects of milk-protein-derived peptides with antihypertensive and ACE-inhibitory activity. International Dairy Journal, 2006. 16(11): p. 1277-1293.

44. Salami, M., et al., Biological activity of camel milk casein following enzymatic digestion. Journal of Dairy Research, 2011. 78(4): p. 471-8.

45. Sibel Akalın, A., Dairy-derived antimicrobial peptides: Action mechanisms, pharmaceutical uses and production proposals. Trends in Food Science \& Technology, 2014. 36(2): p. 79-95.

46. Onuh, J.O., et al., In vitro antioxidant properties of chicken skin enzymatic protein hydrolysates and membrane fractions. Food Chemistry, 2014. 150(0): p. 366-373.

47. Segura-Campos, M.R., L.A. Chel-Guerrero, and D.A. Betancur-Ancona, Purification of angiotensin I-converting enzyme inhibitory peptides from a cowpea (Vigna unguiculata) enzymatic hydrolysate. Process Biochemistry, 2011. 46(4): p. 864-872.

48. Bamdad, F., J. Wu, and L. AU - Chen, - Effects of enzymatic hydrolysis on molecular structure and antioxidant activity of barley hordein. Journal of Cereal Science, 2011. 54: p. 20-28.

49. Girgih, A., et al., Kinetics of Enzyme Inhibition and Antihypertensive Effects of Hemp Seed (Cannabis sativa L.) Protein Hydrolysates. Journal of the American Oil Chemists' Society, 2011. 88(11): p. 1767-1774.

50. Alashi, A.M., et al., Antioxidant properties of Australian canola meal protein hydrolysates. Food Chemistry, 2014. 146(0): p. 500-506.

51. Mullally, M.M., H. Meisel, and R.J. FitzGerald, Angiotensin-I-converting enzyme inhibitory activities of gastric and pancreatic proteinase digests of whey proteins. International Dairy Journal, 1997. 7(5): p. 299-303.

52. Strömstedt, A.A., et al., Interaction between amphiphilic peptides and phospholipid membranes. Current Opinion in Colloid \& Interface Science, 2010. 15(6): p. 467-478. 